\title{
ANALYSIS OF SKILL CRITICAL THINKING STUDENTS ON LEARNING MATHEMATICS CURRICULUM 2013 CLASS V SDN 59 PEKANBARU
}

\author{
Cindy Rahmadani Putri \\ Universitas Riau, Pekanbaru, Indonesia \\ cindyrahmadaniputri@gmail.com
}

\begin{abstract}
Critical thinking skills are very important owned, because having critical thinking skills can help us think logically in overcoming the problems we face and looking for and developing alternative solutions to those problems. This study aims to identify and describe student's critical thinking skills in mathematics learning curriculum 2013 class V SDN 59 Pekanbaru. This research was conducted on January 22, 2020. Research subjects totaled 35 students consisting of 19 male students and 16 female students. This type of research is qualitative research. Data collection instruments in the form of test questions consisting of 5 essay questions and interview guidelines conducted on several students. The results showed $60 \%$ in the very low category, $27.5 \%$ in the low category, $8.5 \%$ in the medium category, and 2.8 in the high and very high categories. Based on the result of data analysis. it can be concluded that the critical thinking skills of studnts in learning mathematics in curriculum 2013 class V SDN 59 Pekanbaru are in the very low category.
\end{abstract}

Keywords: critical thingking skills, mathematics, primary school

\section{ANALISIS KETERAMPILAN BERPIKIR KRITIS SISWA PADA PEMBELAJARAN MATEMATIKA KURIKULUM 2013 KELAS V SDN 59 PEKANBARU}

\begin{abstract}
ABSTRAK
Keterampilan berpikir kritis sangat penting dimiliki, karena dengan memiliki keterampilan berpikir kritis dapat membantu kita berpikir logis dalam mengatasi permasalahan yang kita hadapi dan mencari serta mengembangkan alternatif pemecahan bagi permasalahan tersebut. Berdasakan hal tersebut dilakukan penelitian yang bertujuan untuk mengidentifikasi dan mendeskripsikan keterampilan berpikir kritis siswa pada pembelajaran matematika kurikulum 2013 kelas V SDN 59 Pekanbaru. Penelitian ini dilaksanakan pada tanggal 22 Januari 2020. Subjek penelitian berjumlah 35 siswa yang terdiri dari 19 siswa laki-laki dan 16 siswa perempuan. Jenis penelitian ini adalah penelitian kualitatif. Instrumen pengumpulan data yaitu berupa soal tes yang terdiri dari 5 soal essay dan pedoman wawancara yang dilakukan pada beberapa siswa. Hasil penelitian menujukkan $60 \%$ pada kategori sangat rendah, $27.5 \%$ pada kategori rendah, $8.5 \%$ pada kategori sedang, dan 2.8 pada kategori tinggi dan sangat tinggi. Berdasarkan hasil analisis data yang peneliti lakukan, dapat disimpulkan bahwa keterampilan berpikir siswa pada pembelajaran matematika kurikulum 2013 kelas V SDN 59 Pekanbaru berada pada kategori sangat rendah.
\end{abstract}

Kata Kunci: keterampilan berpikir kritis, matematika, sekolah dasar

\begin{tabular}{|c|c|c|}
\hline Submitted & Accepted & Published \\
\hline 22 Mei 2020 & 27 Juli 2020 & 25 September 2020 \\
\hline
\end{tabular}

\begin{tabular}{|l|l|l|l|l|}
\hline Citation & $:$ & $\begin{array}{r}\text { Putri , C.R. (2020). Analysis Of Skill Critical Thinking Students On Learning Mathematics Curriculum 2013 Class V } \\
\text { SDN 59 Pekanbaru. Jurnal PAJAR (Pendidikan dan Pengajaran), 4(5), 965-974. DOI : } \\
\text { http://dx.doi.org/10.33578/pjr.v4i5.8028. }\end{array}$ \\
\hline
\end{tabular}

\section{PENDAHULUAN}

Pendidikan matematika sangat diperlukan siswa sejak di Sekolah Dasar. Dalam mempelajari matematika, siswa tidak hanya terpaku dengan teori atau konsep-konsep saja, tetapi juga menerapkan matematika sebagai pemahaman siswa untuk memecahkan masalah dalam kehidupan sehari-hari. Dengan matematika siswa juga diharapkan agar dapat mengembangkan keterampilan-keterampilan berpikir dalam memecahkan suatu masalah. Soedjadi (2000) mengemukakan bahwa matematika sekolah adalah unsur-unsur atau bagian-bagian dari matematika yang dipilih berdasarkan atau berorientasi pada kepentingan pendidikan dan perkembangan IPTEK. Marzano (Slavin,2009) menyetakan bahwa salah satu tujuan utama bersekolah adalah 
membentuk kemampuan berpikir kritis siswa dan salah satu mata pelajaran yang dianggap dapat dapat mengajarkan kemampuan berpikir kritis adalah matematika.Matematika sekolah tetap memiliki ciri-ciri yang dimiliki oleh matematika yaitu objek kajian yang abstrak serta berpola pikir deduktif konsisten (Suherman, 2003).

Proses berpikir dan merasakan yang dibangun sejak awal dalam upaya menyelesaikan suatu masalah hendaknya berlangsung secara sengaja dan sampai tuntas. Ketuntasan dalam hal ini dimaksudkan bahwa peserta didik yang menjalani proses tersebut benar-benar telah berlatih dan memberdayakan dan memfungsikan kemampuannya yang ada sehingga ia memahami serta menguasai apa yang dikerjakannya selama proses itu terjadi. Dengan demikian peserta didik harus dilatih agar memiliki kemampuan berpikir kritis.

Menurut Paul, Fisher dan Nosich (2008) berpikir kritis adalah mode berpikir mengenai hal, substansi, atau masalah apa saja dimana si pemikir meningkatkan kualitas pemikirannya dengan menangani secara terampil struktur-struktur yang melekat dalam pemikiran dan menerapkan standar intelektual padanya. Stobaugh (2013) yang menjelaskan bahwa keterampilan berpikir kritis merupakan cara berpikir seseorang yang reflektif dalam mengambil keputusan dan pemevahan masalah untuk menganalisis situasi, mengevaluasi argument, dan menarik kesimpulan yang tepat. Menurut Solso, berpikir merupakan proses yang menghasilkan representasi mental yang baru melalui transformasi informasi yang melibatkan interaksi yang kompleks antara berbagai proses mental seperti penilaian, abstraksi, penalaran, imajinasi, dan pemecahan masalah (Novirin, 2014).

Berpikir kritis diartikan sebagai berpikir nalar, reflektif, bertanggungjawab, dan mahir berpikir. Pendapat yang sama diungkapkan oleh Ennis (1996) mendefinisikan berpikir kritis sebagai suatu proses berpikir dengan tujuan untuk membuat keputusan-keputusan yang dapat dipertanggungjawabkan mengenai apa yang akan diyakini dan apa yang akan dilakukan.
Berdasarkan pendapat beberapa ahli diatas, penulis menyimpulkan bahwa keterampilan berpikir kritis merupakan suatu proses berpikir dalam suatu pemecahan masalah yang dilakukan menggunakan langkah-langkah dalam metode ilmiah yaitu yang berupa merumuskan masalah, analisis malasah, hipotesis, menarik kesimpulan, melakukan evaluasi dan mengambil keputusan.

Beberapa penelitian terdahulu yang mengkaji tentang berpikir kritis yaitu, penelitian Azizah (2018) menyatakan bahwa keterampilan berpikir kritis merupaka salah satu aspek dari kerterampilan pemecahan masalah dan hendaknya guru mengembangkan evaluasi yang cenderung pada keterampilan untuk memecahkan masalah, memformulasikan simpulan, menghitung kemungkinan, atau membuat suatu keputusan. Susanto (2015) menyatakan bahawa upaya untuk pembentukan kemampuan berpikir kritis siswa yang optimal mensyaratkan adanya kelas yang interaktif, siswa dipandang sebagai pemikir bukan seorang yang diajarkan, dan pengajar berperan sebagai mediator, fasilitator, dan motivator yang membantu siswa dalam belajar bukan mengajar.

Hasil penelitian Susilowati (2017) menyimpulkan bahwa keterampilan berpikir kritis yang masih tergolong kurang mengindikasikan bahwa perlu diadakan evaluasi terhadap proses kegiatan pembelajaran yang digunakan di dalam kelas, karena pada dasarnya keterampilan berpikir kritis siswa dapat dilatih dan diasah dalam proses pembelajaran. Adeyeme (2012) menyatakan bahwa pemikiran kritis sangat penting dalam suatu proses belajar. Ada dua fase dalam proses ini, yaitu yang pertama siswa membangun pemikirannya berupa gagasan dasar, prinsip dan teori yang melekat dalam konten. Fase ini disebut internalisasi. Fase kedua terjadi apabila siswa secara efektif menggunakan gagasan, prinsip, atau teori tersebut dalam kehidupan sebagai bentuk penerapan. Penerapan keterampilan berpikir kritits dalam pembelajaran sangat penting.

Pada dasarnya kemampuan berpikir kritis erat kaitannya dengan proses berpikir kritis dan indikator-indikatornya. Indikator kemampuan berpikir kritis menurut Ennis (Hassoubah, 2004) terdapat dua belas indikator kemampuan berpikir 
kritis yang dikelompokkan dalam empat kelompok keterampilan berpikir. Indikator berpikir kritis dapat dilihat dari karakteristik-nya sehingga dengan memiliki karakteristik tersebut seseorang dapat dikatakan telah memiliki kemampuan berpikir kritis. Pada penelitian ini penulis menggunakan indikator menurut Facion (Filsaime, 2008) yang mengungkapkan empat kecakapan berpikir kritis utama yang terlibat di dalam proses berpikir kritis, yaitu:

a. Interpretasi

Menginterpretasi adalah memahami dan mengekspresikan makna atau signifi-kansi dari berbagai macam pengalaman, situasi, data, kejadian-kejadian, penilai-an, kebiasaan, atau adat, kepercayaan-kepercayaan, aturan-aturan, prosedur atau kriteria-kriteria.

b. Analisis

Analisis adalah mengidentifikasi hubungan-hubungan inferensial yang dimaksud dan aktual diantara pernyata-an-pernyataan, pertanyaan-pertanyaan, konsep-konsep, deskripsideskripsi atau bentuk-bentuk representasi lainnya yangdimaksudkan untuk mengekspresikan kepercayaan-kepercayaan, penilaian, pengalamanpengalaman, alasan-alasan, informasi atau opiniopini.

c. Evaluasi

Evaluasi berarti menaksir kredibilitas pernyataan-pernyataan atau represen-tasirepresentasi yang merupakan laporan-laporan atau deskripsi-deskripsi dari persepsi, pengalaman, situasi, penilaian, kepercayaan atau opini seseorang, dan menaksir kekuatan logis dari hubungan-hubungan inferensial atau dimaksud diantara pernyataan-pernya-taan, deskripsideskripsi, pertanyaan-pertanyaan, atau bentukbentuk representasi lainnya.

d. Inferensi

Inferensi berarti mengidentifikasi dan memperoleh unsur-unsur yang diperlukan untuk membuat kesimpulan-kesimpulan yang masuk akal, membuat dugaan-dugaan dan hipotesis, memper-timbangkan informasi yang relevan dan menyimpulkan konsekuensi-konsekuensi dari data, situasi-situasi, pertanyan-pertanyaan atau bentuk-bentuk representasi lainya.
Matematika memiliki peranan penting dalam membentuk dan mengembangkan keterampilan berpikir nalar, logis, sistematis dan kritis. Namun kenyatannya, pelaksanaan pembelajaran matematika disekolah belum sepenuhnya melatih kemampuan berpikir kritis siswa. Sampai saat ini perhatian pengembangan kemampuan untuk berfikir kritis masih relatif rendah sehingga masih terbuka peluang untuk mengesplorasi kemampuan berfikir kritis serta pengembangannya.

Keterampilan berpikir kritis siswa Indonesia masih rendah, hal ini ditunjukkan pada hasil Trends in International Mathematics and Science Study (TIMSS) tahun 2015 bahwa skor Matematika siswa-siwi Indonesia berada pada peringkat 45-50 (Azizah, 2108). Kemampuan siswa-siswi Indonesia dalam mengerjakan soalsoal dengan domain bernalar juga menunjukkan pada kemampuan yang masih sangat minim. Mengacu pada temuan tersebut, pelaksanaan pembelajaran matematika seharusnya tidak hanya menuntut siswa untuk menjawab soal dengan benar saja, tetapi perlu mendorong siswa agar memunculkan ide-ide baru dengan pondasi konsep yang diajarkan.

Tujuan diberlakukannya kurikulum 2013 di Indonesia yaitu untuk megembangkan keterampilan berpikir tingkat tinggi (higher order thingking sklill) atau HOTS yang salah satunya yaitu keterampilan berpikir kritis (critical thingkng skills). Sebagaimana keputusan didalam Permendikbud Nomor 24 Tahun 2016 tentang Kompetensi Inti (KI) dan Kompetensi Dasar Pelajaran Kurikulum 2013 pada Pendidikan Dasar dan Pendidikan Menengah, KI.3 untuk Pendidikan Dasar yaitu: Memahami pengetahuan factual, konseptual, prodesural, dan metakognitif pada tingkat dasar dengan cara mengamati, menanya, dan mencoba berdasarkan rasa ingin tahu tentang dirinya, makhluk ciptaan Tuhan dan kegiatannya, dan benda-benda yang dijumpainya di rumah, si sekolah, dan tempat bermain. KI.4: Menunjukkan keterampilan berfikir dan bertindak kreatif, produktif, kritis, mandiri, kolaboratif, dan kominukatif. Dalam bahasa yang jelas, sistematis, logos dan kritis, dalam karya yang estetis, dalam 
gerakan yang mencerminkan anak sehat, dan tindakan yang mencerminkan perilaku anak sesuai dengan tahap perkembangannya (Kemdikbud, 2016).

\section{METODE PENELITIAN}

Jenis penelitian ini adalah penelitian deskriptif dengan pendekatan kualitatif. Penelitian kualitatif merupakan penelitian yang mendeskripsikan dan memberikan suatu fenomena apa adanya dengan mengambarkan simbol atau tanda yang ditelitinya sesuai dengan sesungguhnya dan dalam konteksnya (Yusuf, 2017). Populasi pada penelitian ini adalah siswa kelas V SDN 59 Pekanbaru. Dikarenakan penelitian yang dilakukan merupakan penelitian kualitatif, penentuan sample dilakukan secara sengaja yaitu pada siswa kelas VB SDN 59 Pekanbaru sebanyak 35 siswa.
Teknik pengumpulan data menggunakan tes dan wawancara. Soal tes terdiri dari 5 soal untuk mengukur kemampuan berpikir kritis siswa. Data yang terkumpul kemudian dianalisis menggunakan analisis deskriptif kualitatif menurut Miles dan Huberman dalam Sugiyono aktivitas dalam analisis data meliputi data reduction (reduksi data), data display (penyajian data), dan conclusion drawing/verification (penarikan kesimpulan) (Sugiyono, 2011). Sebelum melakukan tes kepada siswa perlu dipersiapkan pedoman (rubrik) penilaian yang diujikan sebagai pedoman dalam penyusunan soal tes tertulis. Penilaian terhadap hasil tes tertulis siswa dilakukan secara objektif dan hanya berfokus pada aspek-aspek yang berkaitan dengan kemampuan berpikir kritis. Kriteria penskoran yang digunakan adalah skor rubrik yang diadaptasi dari Karim (2015).

Tabel 1. Rubrik Penilaian Soal

\begin{tabular}{|c|c|c|}
\hline Indikator Umum & Indikator & Skor \\
\hline \multirow[t]{5}{*}{ Interpretasi } & Tidak menuliskan yang diketahui dan yang ditanyakan & 0 \\
\hline & Menulis yang diketahui dan yang ditanyakan dengan tidak tepat. & 1 \\
\hline & $\begin{array}{l}\text { Menuliskan yang dikethui saja dengan tepat atau yang ditanyakan } \\
\text { saja dengan tepat. }\end{array}$ & 2 \\
\hline & Menulis yang diketahui dari soal dengan tepat tetapi kurang lengkap. & 3 \\
\hline & $\begin{array}{l}\text { Menulis yang diketahui dan ditanyakan dari soal dengan tepat dan } \\
\text { lengkap. }\end{array}$ & 4 \\
\hline \multirow[t]{5}{*}{ Analisis } & Tidak membuat model matematika dari soal yang diberikan. & 0 \\
\hline & $\begin{array}{l}\text { Membuat model matematika dari soal yang diberikan tetapi tidak } \\
\text { tepat. }\end{array}$ & 1 \\
\hline & $\begin{array}{l}\text { Membuat model matematika dari soal yang diberikan dengan tepat } \\
\text { tanpa memberi penjelasan. }\end{array}$ & 2 \\
\hline & $\begin{array}{l}\text { Membuat model matematika dari soal yang diberikan dengan tepat } \\
\text { tetapi ada kesalahan dalam penjelasan. }\end{array}$ & 3 \\
\hline & $\begin{array}{l}\text { Membuat model matematika dari soal yang diberikan dan memberi } \\
\text { penjelasan yang benar dan lengkap. }\end{array}$ & 4 \\
\hline \multirow[t]{6}{*}{ Evaluasi } & Tidak menggunakan strategi dalam menyelesaikan soal. & 0 \\
\hline & $\begin{array}{l}\text { Menggunakan strategi yang tidak tepat dan tidak lengkap dalam } \\
\text { menyelesaikan soal. }\end{array}$ & 1 \\
\hline & $\begin{array}{l}\text { Menggunakan strategi yang tepat dalam menyelesaikan soal, tetapi } \\
\text { tidak lengkap atau menggunakan strategi yang tidak tepat tetapi }\end{array}$ & \\
\hline & lengkap dalam menyelesaikan soal. & 2 \\
\hline & $\begin{array}{l}\text { Menggunakan strategi yang tepat dalam menyelesaikan soal, lengkap } \\
\text { tetapi melakukan kesalahan dalam perhitungan atau penjelasan. }\end{array}$ & 3 \\
\hline & $\begin{array}{l}\text { Menggunakan strategi yang tepat dalam menyelesaikan soal, lengkap } \\
\text { dan benar dalam melakukan perhitungan atau penjelasan. }\end{array}$ & 4 \\
\hline \multirow[t]{2}{*}{ Inferensi } & Tidak membuat kesimpulan. & 0 \\
\hline & $\begin{array}{l}\text { Membuat kesimpulan yang tidak tepat dan tidak sesuai dengan } \\
\text { konteks soal. }\end{array}$ & 1 \\
\hline
\end{tabular}


Membuat kesimulan yang tidak tepat meskipun disesuaikan dengan konteks soal.

Membuat kesimpulan dengan tepat, sesuai dengan konteks tetapi tidak lengkap.

Membuat kesimpulan dengan tepat, sesuai dengan konteks soal dan lengkap.

Adapun cara perhitungan persentase adalah sebagai berikut:

Nilai Persentasi $=\frac{\text { Skor perolehan }}{\text { Skor } \text { maksimal }} \times 100 \%$
Nilai persentase kemampuan berpikir kritis yang diperolah dari perhitungan kemudian dikategorikan sesuai dengan tabel berikut:

Tabel 2. Kategori Persentase Kemampuan Berpikir Kritis

\begin{tabular}{cc}
\hline Interpretasi $(\%)$ & Kategori \\
\hline $81.25<\mathrm{X} \leq 100$ & Sangat Tinggi \\
$71.5<\mathrm{X} \leq 81.25$ & Tinggi \\
$62.5<\mathrm{X} \leq 71.5$ & Sedang \\
$43.75<\mathrm{X} \leq 62.5$ & Rendah \\
$0<\mathrm{X} \leq 43.75$ & Sangat Rendah \\
\hline
\end{tabular}

Adaptasi Karim (2015)

\section{HASIL DAN PEMBAHASAN}

Berdasarkan hasil temuan di lapangan, keterampilan berpikir kritis siswa pada pembelajaran Matematika Kurikulum 2013 SD Negeri 59 Pekanbaru berada pada kategori sangat rendah. Persentase siswa pada setiap kategori yaitu terdapat $60 \%$ siswa berada pada kategori sangat rendah, $25.7 \%$ siswa pada kategori rendah, $8.5 \%$ pada kategori sedang, serta $2.8 \%$ pada kategori tinggi dan sangat tinggi. Hasil rata-rata masingmasing aspek indikator keterampilan berpikir kritis siswa dapat dilihat pada tabel 3 di bawah ini.

Tabel 3. Frekuensi Keterampilan Berpikir Kritis Siswa per Indikator

\begin{tabular}{|c|c|c|c|c|c|c|c|c|}
\hline \multirow[t]{3}{*}{ Kategori } & \multicolumn{8}{|c|}{ Indikator } \\
\hline & \multicolumn{2}{|c|}{ (1) } & \multicolumn{2}{|c|}{ (2) } & \multicolumn{2}{|c|}{ (3) } & \multicolumn{2}{|c|}{ (4) } \\
\hline & $\mathrm{F}$ & $\%$ & $\mathrm{f}$ & $\%$ & $\mathrm{~F}$ & $\%$ & $\mathrm{~F}$ & $\%$ \\
\hline Sangat Tinggi & 4 & 11.4 & 1 & 2.8 & 3 & 8.6 & 2 & 5.7 \\
\hline Tinggi & 1 & 2.8 & 8 & 22.9 & 5 & 14.3 & 1 & 2.8 \\
\hline Sedang & 0 & 0 & 4 & 11.4 & 5 & 14.3 & 2 & 5.7 \\
\hline Rendah & 0 & 0 & 10 & 28.6 & 14 & 40 & 2 & 5.7 \\
\hline Sangat Rendah & 30 & 85.7 & 11 & 31.4 & 8 & 22.9 & 28 & 12 \\
\hline Jumlah & 35 & 100 & 35 & 100 & 35 & 100 & 35 & 100 \\
\hline
\end{tabular}

Dapat dilihat pada tabel 3, keterampilan berpikir kritis siswa per indikator terbagi menjadi 2 kategori yaitu, rendah dan sangat rendah. Keterampilan bepikir kritis siswa dalam menginterpretasi dan menginferensi termasuk kategori yang sangat rendah sedangkan analisis dan evaluasi termasuk dalam kategori rendah. Berikut disajikan jawaban beberapa siswa beserta analisisnya. 


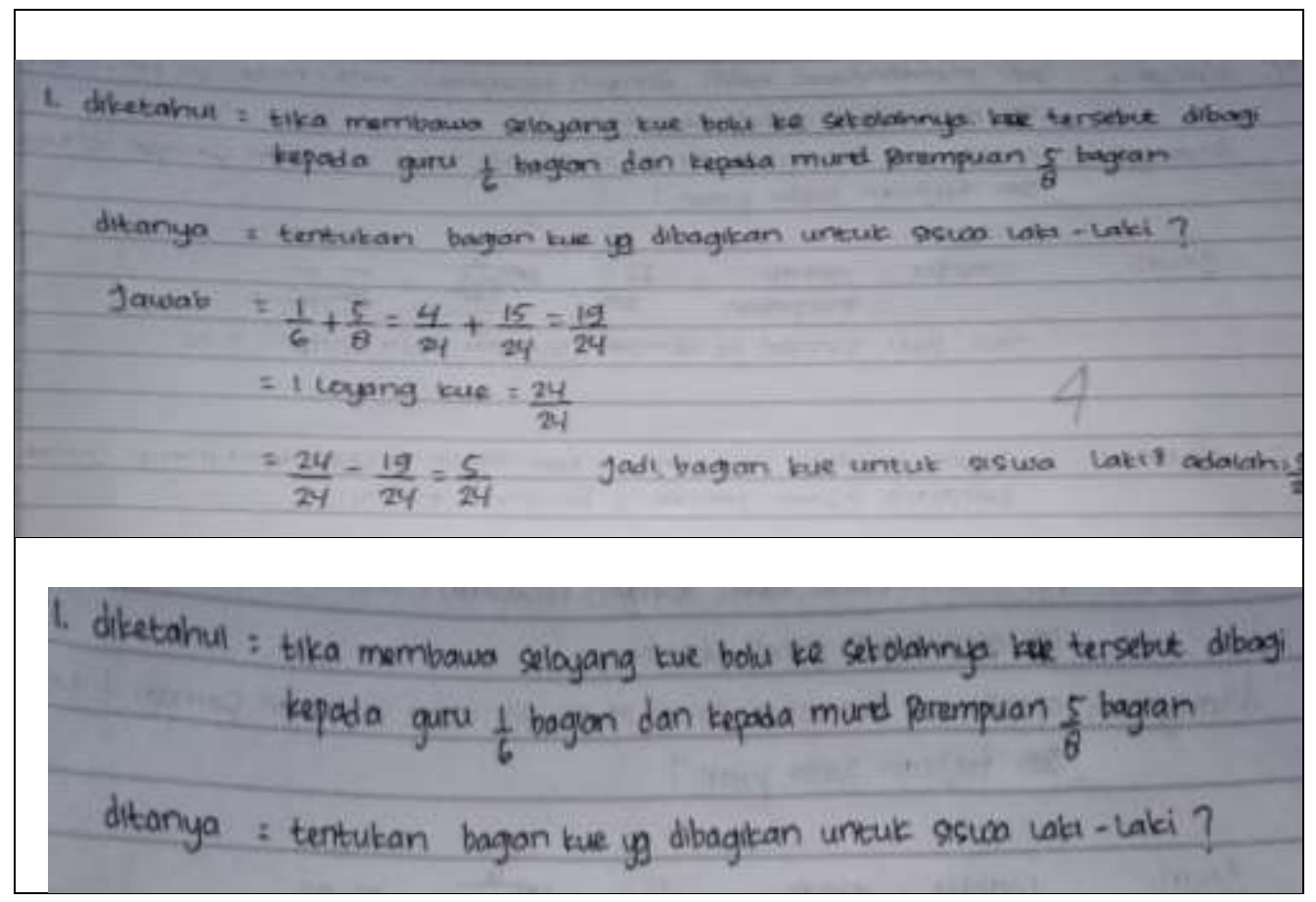

Gambar 1. Hasil Pekerjaan Siswa No.1

Berdasarkan hasil pengerjaan soal keterampilan berpikir kritis siswa pada gambar 1 menunjukkan siswa termasuk dalam kategori sangat tinggi, yaitu sudah memahami soal dan mampu menulis fakta atau informasi yang ada di dalam permasalahan serta mampu menulis kalimat pertanyaan dengan benar. Hal ini merupakan salah satu indikator berpikir kritis yaitu Interpretasi. Namun, sebagian besar siswa belum mampu menuliskan informasi yang ada dalam soal secara menyeluruh.. O'Sullivan \& Dallas (2010) dalam penelitiannya menyebutkan bahwa kemampuan siswa dalam merumuskan suatu permasalahan sangat efektif karena berkaitan dengan topik permasalahan yang akan diselesaikan, membantu memfokuskan gagasan siswa, dan menuntun pada penelitian yang akan dilakukan.

Siswa hanya mengulang kalimat yang terdapat pada soal. Keterampilan merumuskan masalah dalam indikator berpikir kritis merupakan kemampuan identifikasi dan analisis siswa terhadap suatu permasalahan, yaitu mencari fakta atau informasi penting yang kemudian menentukan pokok permasalahan yang akan diselesaikan. Berdasarkan hasil wawancara yang dilakukan, siswa sulit memahami maksud dan tujuan soal. 


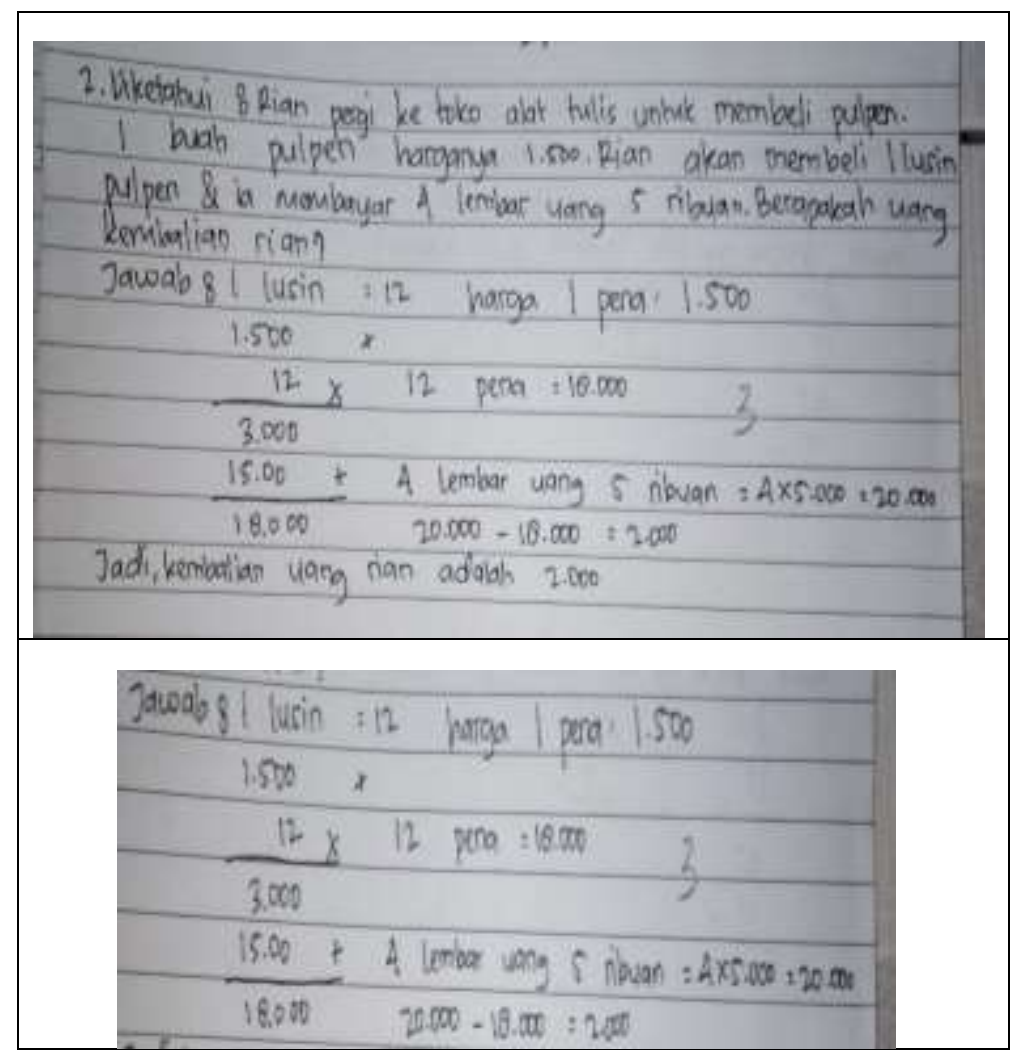

Gambar 2. Hasil Pekerjaan Siswa No.2

Pada gambar 2 merupakan hasil pekerjaan siswa pada kategori tinggi, siswa dapat merencanakan dan sudah mampu melaksanakan strategi penyelesaian masalah dengan lengkap, yaitu menulis cara mengerjakan dalam bentuk kalimat matematika secara matematis. Ariandari (2015) bahwa pada evaluasi belajar dengan konsep HOTS, guru harus selalu menyiapkan soal pertanyaan yang nantinya tidak dijawab secara sederhana, namun melalui strategi pemecahan masalah yang sistematis. Siswa harus mampu menyelesaikan masalah, siswa harus mampu memahami permasalahan yang disajikan, menulis fakta dan mengajukan pertanyaan dengan tepat, merencanakan strategi penyelesaian masalah, dan mengevaluasi keputusan dengan benar. Nugraha (2017) menjelaskan bahwa siswa dengan kemampuan berpikir kritis tinggi cenderung mampu mengkaji ulang pendapat yang diberikan berdasarkan pengetahuan yang sudah dimiliki. 


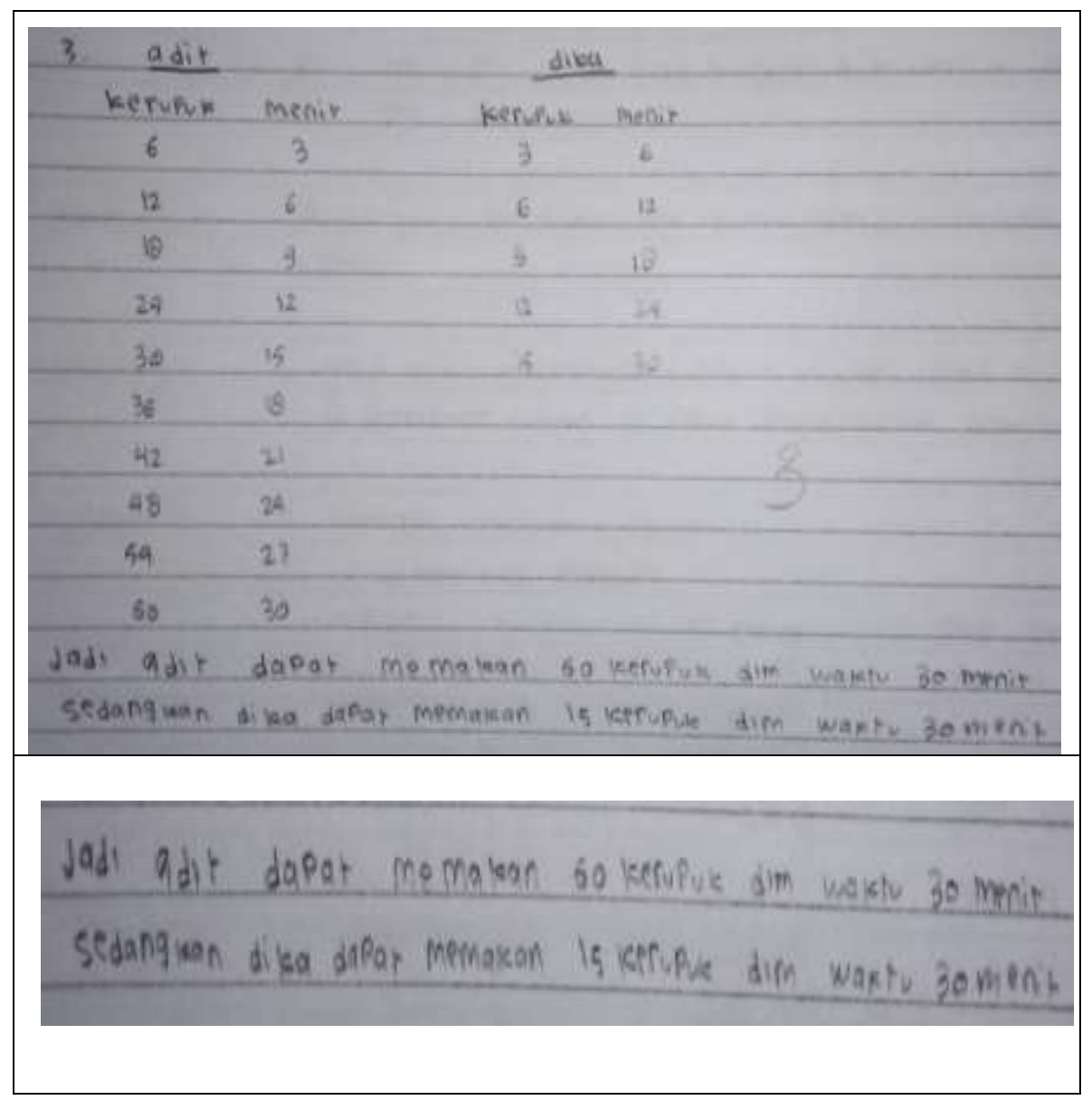

Gambar 3. Hasil Pekerjaan Siswa No.3

Indikator selanjutnya adalah inferensi, membuat kesimpulan dengan tepat sesuai dengan konteks masalah. Siswa pada kategori sangat tinggi ditunjukkan dengan siswa mampu menuliskan atau merumuskan kesimpulan dari fakta atau pengumpulan informasi dan analisis serta evaluasi yang dilakukan untuk penyelesaian permasalahan pada soal.

Antara keempat indikator saling berhubungan dalam pemecahan masalah dan menuntut keterampilan berpikir kritis siswa. Hal ini sesuai dengan hasil penelitian Ariandari (2015) yang menyatakan bahwa berpikir kritis adalah bepikir yang mencakup kegiatan memeriksa, menghubungkan, dan mengevaluasi semua aspek dari situasi atau masalah, termasuk di dalamnya mengumpulkan, mengorganisir, mengingat, dan menganalisa informasi.

\section{Pembahasan}

Hasil analisis keterampilan berpikir kritis siswa pada pembelajaran matematika Kurikulum 2013 menunjukkan capaian kategori yang sangat varian, namun persentase tertinggi menunjukkan bahwa keterampilan berpikir kritis siswa kelas V SD Negeri 59 Pekanbaru berada pada kategori sangat rendah dengan persentase $60 \%$, untuk kategori rendah memiliki persentase $25.7 \%$, pada kategori sedang $8.5 \%$, dan $2.8 \%$ pada kategori tinggi dan sangat tinggi. Hal tersebut bertolak belakang dengan hasil penelitian yang dilakukan Azizah (2018) terkait keterampilan berpikir kritis siswa pada pembelajaran Matematika Kurikulum 2013 kelas V yang mengatakan bahwa sekitar 86\% siswa termasuk dalam kategori kritis atau tinggi. Sebagian besar siswa telah mampu mencapai 
semua indikator keterampilan berpikir kritis. Baik itu dalam merumuskan masalah, menganalisis, dan mengevaluasi.

Setiap indikator memiliki tingkat capaian masing-masing. Terdapat beberapa faktor yang menyebabkan siswa tidak mampu menyelesaikan soal dengan tepat. Yang pertama, yaitu kurangnya minat siswa dalam pelajaran Matematika yang membuat mereka malas dalam mengerjakan soal apapun yang berhubungan dengan Matematika. Minat belajar setiap siswa pastinya berbeda-beda, hal ini ditunjukkan oleh makin tinggi minat belajar siswa maka makin tinggi pula hasil belajarnya, dan begitu sebaliknya makin rendah minat belajar siswa maka makin rendah pula hasil belajarnya. Seseorang dengan minat belajar tinggi akan memiliki kesadaran yang tinggi sehingga menimbulkan rasa ingin tahu dan belajar, cepat untuk memahami dan mengingat pelajaran yang sedang dipelajari serta semakin mudah dalam mengerjakan tugas yang berkaitan dengan pelajaran tersebut. Hal ini sejalan dengan penelitian Wasti (2013) yang menyatakan minat belajar siswa mempengaruhi proses pembelajaran yang secara langsung juga berpengaruh terhadap hasil belajar.

Kurangnya latihan atau terbiasanya siswa dengan soal yang berbasis masalah juga merupakan faktor lain dari rendahnya keterampilan berpikir kritis siswa pada pembelajaran Matematika. Siswa jarang dipertemukan dengan soal-soal yang berkaitan dengan pengembangan pemikiran terhadap pemecahan susatu masalah khususnya dalam pembelajaran matematika. Pengulangan terhadap penyampaian materi dan latihan, dapat membantu siswa ;ebih mendalami dan mengingat materi terkait lebih lama. Hal ini sesuai dengan teori belajar E. Thorndike yang salah satunya adalah Hukum Latihan (law of exercise), yaitu semakin sering suatu tingkah laku diulang atau dilatih (digunakan), maka asosisasi tersebut akan semakin kuat. Pavlov dalam Hanavy (2014) juga berpendapat hal yang sama, dikenal dengan teori Conditioning yaitu memandang bahwa segala tingkah laku manusia tidak lain adalah conditioning, yaitu hasil dari latihan-latihan atau kebiasaan-kebiasaan mereaksi terhadap stimulus tertentu yang dialami di dalam kehidupannya.

\section{SIMPULAN DAN REKOMENDASI}

Berdasarkan hasil analisis yang peneliti temukan, keterampilan berpikir kritis siswa pada pembelajaran Matematika Kurikulum 2013 SD Negeri 59 Pekanbaru berada pada kategori sangat rendah. Persentase siswa pada setiap kategori yaitu terdapat $60 \%$ siswa berada pada kategori sangat rendah, $25.7 \%$ siswa pada kategori rendah, $8.5 \%$ pada kategori sedang, serta $2.8 \%$ pada kategori tinggi dan sangat tinggi.

Saran yang dapat peneliti sampaikan berdasarkan hasil penelitian ini adalah kepada guru dan pihak sekolah dapat merancang kegiatan belajar mengajar yang dapat memberdayakan keterampilan berpikir kritis siswa dan membiasakan serta melatih siswa dengan soal-soal yang menyangkut dengan perkembangan dan penalaran pada siswa.

\section{DAFTAR PUSTAKA}

Adeyemi, S. (2012). Developing Critical Thinking Skills in Students: A Mandate for Higher Education in Nigeria. European Journal of Educational Research.

Ariandari, W. (2015). Mengintegrasikan Higher Order Thinking dalam Pembelajaran Creative Problem Solving. Seminar Nasional Matematika dan Pendidikan Matematika UNY 2015. Universitas Negeri Yogyakarta.

Azizah, M. (2018). Analisis Keterampilan Berpikir Kritis Siswa Sekolah Dasar Pada Kurikulum 2013. Jurnal Penelitian Pendidikan, 61.

Ennis, R. H. (1996). Critical Thinking. USA: Prentice Hall, Inc.

Filsaime, D. (2008). Menguak Kemampuan Berpikit Kritis dan Kreatif. . Jakarta: Diterjemahkan oleh Sunarni ME. Buku Berkualitas Prima.

Fisher, A. (2008). Berpikir Kritis. Jakarta: Erlangga.

Hanavy, M. S. (2014). Konsep Belajar Dan Pembelajaran. Jurnal Lentera Pendidikan. 
Hassoubah, Z. I. (2004). Developing Creative \& Critical Thinking Skills (Cara Berpikit Kreatif dan Kritis). Jakarta: Nuansa.

Karim, N. (2015). Kemampuan Berpikir Kritis Siswa Dalam Pembelajaran Matematika Dengan Menggunakan Model Jucama di Sekolah Menengah Pertama. Jurnal Pendidikan Matematika.

Kemdikbud. (2016). Peraturan Mentri Pendidikan dan Kebudayaan Rebuplik Indonesia nomor 24 tahun 2016 Tentang Kompetensi Inti dan Kompetensi Dasar Pelajaran pada Kurikulum 2013 pada Pendidikan Dasar dan Penddikan Menengah.

Novirin, D. (2014). Efektivitas Penerapan Metode Group Investigation dalam Peningkatan Kemampuan BErpikir Tingkat Tinggi dan Prestasi Belajar Peserta Didik Kelas X Mata Pelajaran Kewirausahaan di SMK PGRI 2 Prabumulih Tahun Ajaran 2013/2014. Skripsi, 101-102.

Nugraha, A. (2017). Analisis Kemampuan Berpikir Kritis ditinjau dari Keterampilan Proses Sains dan Motivasi Belajar melalui Model PBL. Jurnal of Primary.

O'Sullivan, M. (2010). A Collaborative Approarch to Implementing 21 Century Skills in a High School Senior Research Class. Education Libraries, 3-9.

Slavin, R. (2009). Psikolodi Pendidikan : Teori dan Praktik. Jakarta: Edisi ke-9 diterjemahkan oleh Marianto Samosir. PT Indeks.

Soedjadi, R. (2000). Kiat Pendidikan Matematika di Indonesia. Jakarta: Depdiknas.

Stobaugh, R. (2013). Assesing CriticalThinking in Middle and High Schools: Meeting the Common Core. New York: Routledge.

Sugiyono. (2011). Metode Penelitian Kuantitatif Kualitatif dan $R \& D$. Bandung: Alfabeta.

Suherman, E. (2003). Strategi Pembelajaran Matematika Kontemporer. JICA.

Susanto, A. (2015). Teori Belajar dan Pembelajaran di Sekolah Dasar. Jakarta: Prenadamedia Group.

Susilowati, d. (2017). Analisis Keterampilan Berpikir Kritis Siswa Madrasah Aliyah Negeri di Kebupaten Magetan. Prosiding
Seminar Nasional Pendidikan Sains (SNPS).

Wasti, S. (2013). Hubungan Minat Belajar dengan Hasil Belajar Mata Pelajaran Tata Busana Di Madrasah Aliyah Negeri 2 Padang. SRIPSI Padang: Universitas Negeri Padang.

Yusuf, M. (2017). Metode Penelitian. Jakarta: KENCANA. 